\title{
Genetic diversity and character association analysis based on pomological traits in olive (Olea europaea L.)
}

\author{
S. Lal*, O. C. Sharma and D. B. Singh \\ ICAR- Central Institute of Temperate Horticulture, Old Airport, P.O., Rangreth, Srinagar-190 007 (J \& K), INDIA \\ *Crresponding author. E-mail: shivcith@gmail.com
}

Received: October 30, 2016; Revised received: February 23, 2017; Accepted: August 2, 2017

\begin{abstract}
Thirteen exotic genotypes of olive (Olea europaea L.) were studied for the genetic variability, correlation and path coefficient analysis for fruit quality, yield and yield contributing traits at experimental farm of ICAR-CITH, Srinagar during 2009-2013. Maximum variability was recorded for fruit yield and oil content, however, low differences between the phenotypic and genotypic coefficients of variations indicated low environmental influences on the expression of these characters. High heritability coupled with high genetic advance was obtained with fruit yield per plant, acidity, fruit pulp weight, fruit weight and stone weight. Fruit weight $(r=0.329)$, stone weight $(r=0.405)$ and oil content $(r=0.841)$ were the most important traits, which possessed significant positive association with fruit yield per plant. Path coefficient analysis revealed that among the different yield contributing characters oil content (0.875), fruit weight $(0.797)$ followed by acidity $(0.501)$, peroxides value $(0.199)$ and fruit length $(0.054)$ influenced fruit yield per plant directly. The direct effects of these characters on fruit yield were found positive and considerably very high.The selection based on fruit weight, stone weight oil content and yield per plant will be effective for enhancing the fruit and oil yieldand making future olive breeding strategies.
\end{abstract}

Keywords: Character association, Genetic diversity, Olive, Path analysis, Temperate, Yield

\section{INTRODUCTION}

Olive (Olea europaea L.) is one of the subtropical fruit tree species with remarkable cultural and economic importance (Dastkar et al., 2013). It is of great economic importance in Mediterranean countries because of the oil extracted from its fruits (Orlandi et al., 2004). In Asia, cultivation is mostly confined to Iraq, Iran and China however, in India inspite of its vast potential it is grown only in an area of about 707 ha mostly in the Himalayan mountainous region encompassing the three northern states of Jammu and Kashmir, Himachal Pradesh and Uttarakhand hills at an altitude ranging from 1000 to $1300 \mathrm{~m}$ above mean sea level. Among the states Jammu \& Kashmir leads with an area spread in the districts of Doda, Udhampur, Rajouri, Poonch, Kupwara, and Baramulla. The district Rajouri has the maximum area (303 ha) followed by Doda (248 ha) (DOH, 2016). Olive is mostly grown for extraction of oil and also utilized for table purposes and pickles. In India, the demand of olive is increasing very fast due to its peculiar medicinal and antioxidental properties. The Indian olive oil market pegged at Rs. 550 crores by the end of 2012 and hopes to reach 2,5000 MT of worth Rs. 1000 crores in 2020 (IOOC, 2011). Preliminary evaluation revealed that crop has vast potential in the country and their production both for oil and table purposes by increasing the area in mid warm temperate regions not only augment to our oil requirement but can also save foreign exchange to the tune of about 200 crores. From initial performance studies of olive genotypes under temperate and sub-temperate regions showed positive results for fruit and oil yield (Singh et al., 1986 and CITH, 2013) but still there a great scope to enhance productivity of fruit and oil yield. To enhance production and productivity of any cops genetic variability is the prerequisite for any plant breeding program (Khush, 2002). Studies of genetic variability, heritability and correlation between traits can show the extent to which certain traits are genetically determined and which of them have the greatest importance in the selection for favourable characters. In addition to determining the components of variability and the coefficient of heritability, it is also very important in olive breeding to know the relationships existing between traits. Under the impact of selection a change in the correlated interdependent of traits occurs, therefore the testing of values of correlation coefficients must be done all the time. The aim of the present investigation was to determine the components of variability and the coefficients of heritability for yield and yield attributing traits and to observe the inter-relations of such traits.

\section{MATERIALS AND METHODS}

The present study was conducted at research farm of ICAR-Central Institute of Temperate Horticulture (CITH), Srinagar, India during year 2003 to 2013 on 
thirteen exotic olive genotypes viz. Messenese, Pendolino, Etrana, Zatuna, Frontoio, Morolio, Biancollilo, Cipressino, Cornicobra, Coratina, Carignola, Leccino and Picholine which were received from Egypt and University of California, DAVIS campus (USA) via. National Bureau of Plant Genetic Resources (NBPGR), New Delhi. The site is situated at latitude of $34^{0} 05 \mathrm{~N}$ and longitude of $74^{0} 50 \mathrm{E}$ at an altitude of $1640 \mathrm{~m}$ above the mean sea level. Tree spacing was kept $5 \mathrm{~m} \times 5 \mathrm{~m}$ and recommended package of practices followed for better and healthy crop. The primary selection criterion was based on fruits and yield attributes of the genotypes. Individual genotypes were marked in the field. The data were recorded at the time of fruit maturity during summer (Oct.-Nov.) seasons of the each year i.e. 2011, 2012, \& 2013 and data pooled for analysis. Fifty fruit from each genotype were randomly harvested as per maturity index define by (Barranco et al., 2000) and measured various traits. The data were collected on fruit length $(\mathrm{mm})$, fruit weight $(\mathrm{g})$, fruit diameter $(\mathrm{mm})$, pulp weight $(\mathrm{g})$, stone diameter $(\mathrm{mm})$, stone weight $(\mathrm{g})$, acidity $(\%)$, oil content $(\%)$, peroxidise and fruit yield ( $\mathrm{kg} / \mathrm{plant})$. The length and diameter of the fruit was measured with a digital verniercaliper. The stone were manually separated from the fruits and stone weight and stone diameter traits were measured. Approximately $1 \mathrm{~kg} /$ tree/treatment of fruits was ground to a paste using a hammer mill, the sample was thoroughly mixed and approximately $700 \mathrm{~g}$ of the paste were placed into a mixing jar for $20 \mathrm{~min}$ stirring. $100 \mathrm{ml}$ of boiling water was added to the sample, and it was further stirred for $10 \mathrm{~min}$. The sample was then centrifuged for $1 \mathrm{~min}$ to allow oil separation from the water. The oil was collected in a graduate cylinder and decanted overnight. Oil content was determined by extracting dryolive paste with hexane using a Soxhlet apparatus (AFNOR, 1984). Oil acidity given as \% of oleic acid was determined according to the A.F.NOR T, 60- 204 method (AFNOR, 1984) and peroxide value oil was carried out following the analytical methods described in Regulation EEC/2568/91 of the commission of the European Union (EEC, 1991). The experiment was conducted under randomized block design replicated three times and pooled data of three years were analyzed (Gomez and Gomez, 1984). The genotypic and phenotypic coefficients of variation were calculated (Burton and De Vane,1953). Heritability and genetic advance were calculated according to Allard (1960) and genetic gain was estimated using the method of Johnson et al. (1955). Genotypic and phenotypic correlations were calculated as per Al-Jibouri et al. (1958). The direct and indirect paths were obtained according to the method of Dewey and Lu (1959).

\section{RESULTS AND DISCUSSION}

The extent of variability in respect of range, mean, phenotypic and genotypic coefficients of variation, heritability and genetic advance is given in Table 1 . Maximum variability was recorded in fruit yield followed by oil content, fruit length, peroxides value, fruit width, fruit weight, fruit pulp weight, acidity and lowest in stone weight. Considerable variability was observed for all the traits under study indicating the diversity of material and its amenability to selection. Similar kind of variability was also reported in yield and yield attributes by Fontanzza et al. (1999), Hosseini et al. (2008) and Dastkar et al. (2013) in olive. The magnitude of PCV was slightly higher than the corresponding GCV for minerals contents indicating lesser influence of environment on yield and yield attributes in olive. Maximum PCV and GCV were estimated for yield per plant followed by acidity, fruit pulp weight, fruit weight and stone weight and lowest in fruit length. Heritable portion of variation can be deduced by computing the heritability and genetic advance as percentage of mean. High heritability $(>95 \%)$ was estimated for traits such as fruit yield per plant, acidity, fruit pulp weight, fruit weight and stone weight. A high heritability for the traits indicates that a large portion of phenotypic variance is contributed through genotypic variance and therefore a reliable selection can be made for these traits. The lowest but moderate heritability for head weight (93.3\%) indicates a trait is more influenced by environment than other traits. Effectiveness and potentiality of the traits under selection could be revealed by an assessment of genetic gain. Genetic advance as percentage of mean varied from 16.39 to $179.24 \%$. It was estimated high $(>40 \%)$ for yield per plant followed by acidity, fruit pulp weight, fruit weight and stone weight and low $(<30 \%)$ for fruit length, fruit width, oil content and peroxidise value of oil.Heritability estimates along with genetic advance as percentage of mean, together, are more useful in predicting the gain under selection than either of them alone (Singh and Chaudhary, 1977). In the present study, a high heritability accompanied by a high genetic advance for yield per plant followed by acidity, fruit pulp weight, stone weight and fruit weight clearly suggest the role of additive gene action and thus a high genetic gain is expected from hybridization followed by selection for these traits. Although high heritability estimate have been found to be effective in the selection of superior genotypes on the basis of phenotypic performance, Johnson et al. (1955) suggested that heritability estimates along with genetic advance will be more useful in predicting the effect for selecting the best individual suggested that genotypic coefficient of variation along with heritability estimates would give better idea about the efficiency of selection. However, traits like peroxidise value, oil content, fruit width and fruit length showed a low genetic advance along with high heritability and thus 
reflecting the regulation of the previously mentioned traits through non-additive gene, which could be exploited for the development of synthetics and hybrids through heterosis breeding. Moderate heritability along with moderate to high genetic advance for head weight suggests the involvement of both additive and non-additive genes, which could be improved through reciprocal recurrent selection.

Mutual relationship between fruit quality, yield and its contributing traits (Table 2) revealed that in most of the cases the genotypic correlation coefficient were higher than the corresponding phenotypic correlation coefficient indicating strong inherent relation between the traits but suppressing effect of the environment, which modified the phenotypic expression of these characters by reducing phenotypic coefficient values. Nevertheless, the difference between genotypic and phenotypic correlation coefficients for yield per plant is wider, which reveals that the apparent association is not only due to genes but also due to favourable influence of environment. Fruit length is genotypically and phenotypically significantly positively associated with fruit weight and similarly fruit width is exhibited significant positively associated with fruit weight and fruit length. Fruit pulp thickness showed positive significant linked to fruit weight, fruit length and fruit width. Stone weight revealed positive significant association with fruit weight, fruit length, fruit width, fruit pulp weight and fruit pulp weight whereas acidity exhibited positive significant association with fruit length. Oil content showed positive significant association with fruit length however negative with acidity. Peroxidise value exhibited positive significant association with fruit weight, fruit width, fruit pulp weight and stone weight. Yield per plant showed positively significant linkage with fruit weight, stone diameter and oil content, however, non significant association with rest of the traits. It may be inferred that the selection, either based on these traits in combination or alone, would be beneficial to identify the genotypes having higher fruit quality and yield. The result suggests that olive breeding should emphasize the selection of higher fruit weight, stone diameter and oil content for high yield however higher fruit length to maintain the higher oil content in fruits. Thereby significant correlations of yield contributing traits suggested the scope of direct and indirect effective selections for further improvement. These findings were also supported by Leon (2005), Lorenzo, (2004) and Del and Caballero (2008) in olive and Saran et al. (2007) in Indian jujube.

In general, correlation coefficient indicated only the interrelationships between any two traits without tracing any possible causes of such interrelationships. In such situation, the path coefficient analysis at genotypic level (Table 3) was done to partition the correlation coefficient into direct and indirect effects.

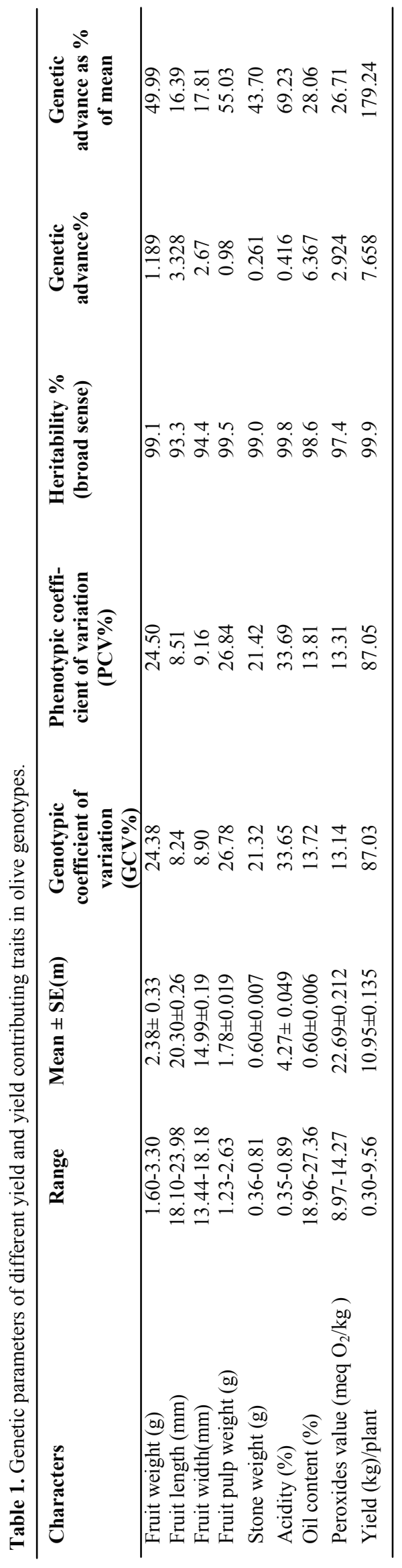


S. Lal et al. / J. Appl. \& Nat. Sci. 9 (3): 1551-1556 (2017)

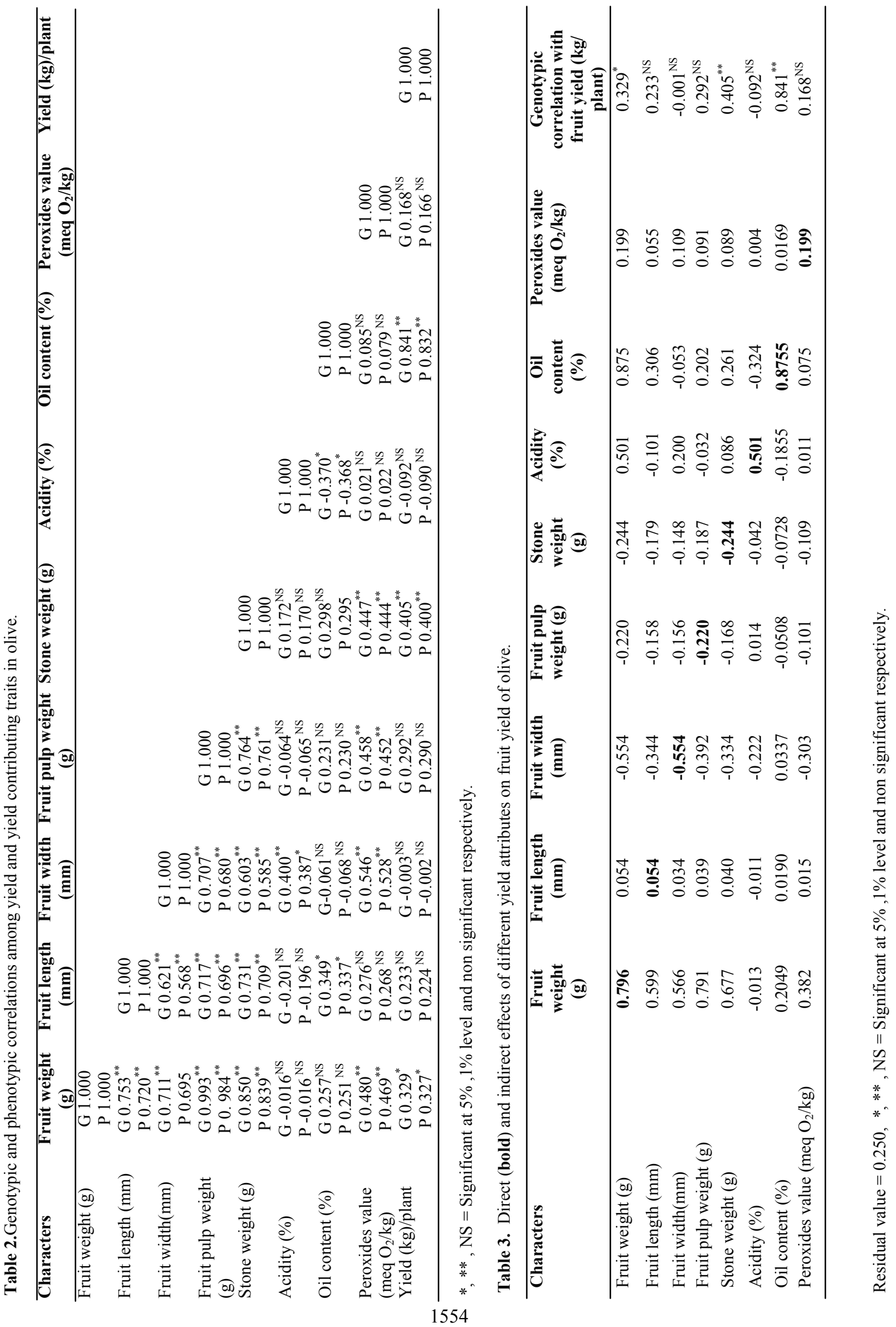


Yield per plant was taken as dependent variable while computing the path coefficient. It was revealed that considerably highest positive direct effect on fruit yield was exhibited by oil content $(0.875)$, fruit weight $(0.797)$ followed by acidity $(0.501)$, peroxides value ( 0.199$)$ and fruit length $(0.054)$ however, negative direct effect exhibited by fruit width $(-0.554)$, fruit pulp weight $(-0.220)$, stone weight $(-0.244)$. Among them fruit weight, stone weight and oil content were highly correlated with fruit yield per plant at genotypic level. The direct effects of these traits on fruit yield could be considered as causes of such high correlation. Fruit length, acidity and peroxidise value exhibited high and positive direct effects on fruit yield but their correlations with yield per plant was non -significant. High positive indirect effect of fruit weight through fruit length, acidity, oil content and peroxidise value increased the correlation of the character with fruit yield per plant to be significant. Similarly high and positive indirect effect of stone weight through fruit weight fruit length and oil content caused the significant correlation of the character with fruit yield per plant. The character fruit length had negative direct effect on fruit yield, which suggests that the selection for higher fruit length types with high yield is possible. Similar reports are available from Lorenzo (2004) in olive, Sofiet al. (2001) in apricot and Saran et al. (2007) in ber who observed that the significant positive correlation of these traits with fruit yield was due to fruit weight. The residual effect of the present study was 0.164 indicating that the characters studied contributed $83.6 \%$ of the yield. It is suggested that maximum emphasis should be given on the above characters in selecting olive genotypes with higher yield.

\section{Conclusion}

This is the first report on association of various pomological traits, mainly contributing to the fruit yield, oil content and quality in olive under temperate region of India. The study showed maximum variability for fruit yield and oil content however, highest heritability for fruit yield per plant, acidity, fruit pulp weight, fruit weight and stone weight. Fruit weight, stone weight and oil content were significantly positive associated with fruit yield per plant whereas, path coefficient analysis revealed that among the different yield contributing characters, oil content, fruit weight had influenced fruit yield per plant directly. Hence, the knowledge of inheritance and interrelationships among fruit quality, yield and yield attributing traits would be helpful in adopting the suitable breeding approaches and identification and selection of high oil and fruit yielding olive genotypes.

\section{REFERENCES}

AFNOR.(1984). Recueil des normesfrançaises des corps gras, grainesoléagineuses et produitsdérivés. 3ème édition, ED. AFNOR. Paris.

Al-Jibouri, H.A., Millar, P.A. and Robinson, H.P.(1958). Genotypic and environmental variances and co-variances in upland cotton crosses in inter-specific origin. Agron J., 50:633-636.

Allard, R.W. (1960) Principles of plant breeding. John Wiley and Sons, New York.

Barranco, N.D., Cimato, A., Fiorion. P., Romero, L., Touzani, A., Castaneda, C., Serafini, F. and Navas, I.T. (2000). World Catalogue of Olive Varieties. International Olive Oil Council (IOOC). 360 pp.

Burton, G.W. and Devane, E.V.M.(1953) Estimating heritability from replicated clonal material. Agron J.,45: 478- 481.

CITH. (2013). Central Institute of Temperate Horticulture annual report 2012 - 13. ICAR-Central Institute of Temperate Horticulture, Srinagar, J\&K, pp 14.

Dastkar, E., Soleimanib, A., Jafaryc, H. and Naghavid, M.R. (2013). Genetic and morphological variation in Iranian olive (Oleaeuropaea L.) germplasm. Crop Breed J.,l3 (2):99-106.

Del, R.C. and Caballero, J.M.(2008). Variability and classification of olive cultivars by fruit weight, flesh/stone ratio and oil percentage. Acta Hort., (ISHS) 791:39-44.

Dewey, J.R .and Lu, K.H.(1959). A correlation and path analysis of components of crested wheat-grass seed productionAgronJ.,51: 515-8.

$\operatorname{DOH}(2016)$. Directorate of Horticulture Kashmir. http:// hortikashmir.gov.in/AREA\%20PROD\%20NET/AP-2005 $-06 . p d f$

EEC.(1991). Commission regulation (EEC) No 2568/91 of 1 July of 1991 on the characteristics of olive oil and olive-residue oil and on the relevant methods of analysis. Official Journal of the European community, L248/ 1-114.

Fontanzza, G., Vergari, G.P., Giorio, G.(1999).Preliminary results of the evaluation of yield component in an F1 segregent populations of olive seedlings from the cross LeccinoxKalamata. Acta Hort., 474: 97-101.

Gomez, K.A. and Gomez, A.A.(1984). Statistical Procedures for Agricultural Research, $2^{\text {nd }}$ John Wiley and Sons Inc., New York.

Hosseini, M.M., Samaee, S.M., Ataei, S., Sadeghi, A. and Mirmansoori, A.(2008). Multivariate analyses of intra-cultivar variation of a local olive cultivar in the northern part of Iran using morphological traits. Acta Hort., (ISHS) 791:65-71.

IOOC (2011).http://www.oliveoiltimes.com/olive-oil- usiness/asia/vn-dalmia/22055.

Johnson, W.W., Robinson,H.F. and Comstock, R.E.(1955). Genotypic and phenotypic correlation in soybeans and their implications in selection. AgronJ.,47:477-482.

Khush, G.S.(2002). Molecular genetics-plant breeder's perspective, p.1-8. In: S.M. Jain, D.S. Brar, and B.S. Ahloowalia (eds.). Molecular techniques in crop improvement. Kluwer Academic Publishers, Dordrecht, The Netherlands.

Leon, L., Del, R. R., Barranco, D. and Rallo, L.(2005). Selection for fruit removal force and related characteristics in olive breeding progenies. Aust J ExpAgric., 45:16431647.

Lorenzo, L. (2004). Phenotypic correlations among agronomic 
traits in olive progenies. Jr. Soc. Hort. Sci.129(2): 271276.

Orlandi, F., Garcia-Mozo, F., Vazquez, E.L., Romano, B., Dominguez, E., Galan, C. and Fornaciari, M.(2004). Phenological olive chilling requirements in Unbria (Italy) and Andalusia (Spain). Pl Biosys.,138: 111-16.

Saran, P.L., Godara, A.K., Lal, G. and Yadav, I.S.(2007). Correlation and path coefficient analysis in ber (ZiziphusmauritianaLamk.) genotypes for yield and yield contributing traits. Indian J Hort., 64(4): 172-175.

Sofi, A.A., Zaffar, G. and Mir, M.S. (2001). Genetic variability and association of component characters for fruit weight in apricot (Prunusarmeniaca L.) cultivars of Kargil (Ladakh). Indian J Hort.,58 (3): 239-243.

Singh, R.K. and Chaudhary, B.D. (1977). Biometrical methods in quantitative genetic analysis. Kalyani Publ., New Delhi.

Singh, R., Rana, H.S. and Chadha, T.R.(1986). Studies on physico-chemical characteristics of some olive (Oleaeuropaea L.) cultivars. p55-59. In: T.R: Chadha, V.P. Bhutani, and J.L. Kaul (eds), Advances in Research on Temperate Fruits. UHF, Nauni, Solan. 